\title{
PHENOLOGICAL VARIABILITY AND RESISTANCE TO LATE SPRING FROST OF COMMON BEECH IN THE INTERNATIONAL PROVENANCE TEST IN BOSNIA AND HERZEGOVINA FENOLOŠKA VARIABILNOST IN ODPORNOST NAVADNE BUKVE NA POZNO POMLADANSKO POZEBO V MEDNARODNEM PROVENIENČNEM POSKUSU V BOSNI IN HERCEGOVINI
}

\author{
Mirzeta MEMIŠEVIĆ HODŽIĆ ${ }^{1}$, Almedin HEBIBOVIĆ ${ }^{\text {, Dalibor BALLIAN }}{ }^{3}$ \\ (1) University of Sarajevo, Faculty of Forestry, mirzeta.memisevic.hodzic@gmail.com \\ (2) Šumarstvo 'Prenj', Konjic, almedin_juve@hotmail.com \\ (3) University of Sarajevo, Faculty of Forestry, Slovenian Forestry Institute, balliandalibor9@gmail.com
}

\begin{abstract}
The research aimed to determine the start, end and duration of leafing phases, the degree of plant damage caused by late spring frost, and the retention of leaves in autumn. The research was conducted in the international common beech provenance test in Bosnia and Herzegovina. The test contains eight provenances from Bosnia and Herzegovina, four from Germany, three from Serbia, two each from Croatia, Romania and Switzerland, and one from Hungary. Leafing phenology, canopy damage caused by late spring frost, and leaf retention were assessed in 2019. Most provenances started opening buds on 17 April 2019. Complete canopy damage affected the highest percentage of plants in provenance BW Bad Wildbad, Germany (68\%), and the lowest in provenance Konjuh Kladanj, Bosnia and Herzegovina (3.2 \%). Provenance Herzogenbuchsee from Switzerland had the highest percentage of winter leaf retention (37.5 \% of plants). The results can be used in choosing provenances that are resistant to low temperatures in zones of late spring and early autumn frost.
\end{abstract}

Key words: common beech, international provenance test, leafing phenophases, frost damage, winter leaf retention

\section{IZVLEČEK}

Namen raziskave je bil določiti začetek, konec in trajanje fenoloških faz, stopnje škode, ki jo povzroči pozno pomladanska pozeba, in zimsko retencijo listja. Raziskava je bila opravljena na območju mednarodnega provenienčnega poskusa navadne bukve v Bosni in Hercegovini. Poskus obsega osem provenienc iz Bosne in Hercegovine, štiri iz Nemčije, tri iz Srbije, po dve iz Hrvaške, Romunije in Švice ter eno iz Madžarske. Leta 2019 so bile ocenjene fenologija listja, škoda na krošnjah zaradi pozno pomladanske pozebe in retencija listja. Pri večini provenienc se je olistanje začelo 17. aprila 2019. Škoda na celotni krošnji je najvišji delež dreves prizadela na provenienci BW Bad Wildba v Nemčiji (68 \%), najmanjši delež pa na provenienci Konjuh Kladanj v Bosni in Hercegovini (3,2 \%). Provenienca Herzogenbuchsee iz Švice je imela najvišji delež zimske retencije listja (37,5 $\%$ dreves). Rezultati so uporabni za izbiro provenienc, ki so odporne na nizke temperature na območjih pozno pomladanske in zgodnje jesenske pozebe.

Ključne besede: navadna bukev, mednarodni provenienčni poskus, fenofaze razvoja listov, škoda po zmrzali, zimska retencija listja

\section{INTRODUCTION}

1 UVOD

Common beech occurs in Bosnia and Herzegovina in mixed forests of beech and fir and in mixed forests of fir, spruce and beech, which occupy an area of $46 \%$ of the total area of all high forests in Bosnia and Herzegovina $(1,652,400$ ha). According to Fukarek (1970) and Ballian (2010), common beech is the most represented species in the total area of forests and forest lands in Bosnia and Herzegovina and is therefore of exceptional economic and ecological importance.

Geßler et al. (2007) stated that the competitive capacity of beech relative to other species, depending on other ecological conditions, could weaken in future climatic conditions, and thus phenological research of common beech has become more important.

Phenological research of common beech was conducted by Muhs (1985), Von Wühlisch et al. (1995) and Liesebach et al. (1999), and in Bosnia and Herzegovina, by Ballian et al. (2015) and Ballian et al. (2019). All of 
this research showed significant intrapopulation and interpopulation variability. Ballian and Zukić (2011) investigated the growth of provenances in the same common beech provenance test in Bosnia and Herzegovina, and Ballian et al. (2012) investigated genetic differentiation of the growth of provenances.

Gordo and Sanz (2010) investigated the impact of climate change on the phenological phases of 29 perennial plants in the Mediterranean region for the period 1943-2003 and concluded that climate change has shifted phenological trends and has particularly impacted spring phenology.

Čufar et al. (2012) analyzed the leaf phenology of European beech (Fagus sylvatica L.) and its variation due to spatial and temporal climatic variability, using a modified data set of the phenological network in Slovenia. The results for the first leaf unfolding of 47 sites (altitudes from 55 to $1,050 \mathrm{~m}$ a.s.l.) and corresponding climate series (52 of precipitation and 38 of temperature) for the period 1955-2007 were collected by the Slovenia Environment Agency. Across the network on average, leaf unfolding occurred from 14 April until 13 May and was delayed by 2.6 days when the altitude increased by 100 $\mathrm{m}$. Annual variation of leaf unfolding was significantly correlated with March and April temperatures. March temperatures had a greater effect at lower elevations and April temperatures had a greater effect at higher elevations. Detailed sub-regional data from a relatively small area with high geographic variability showed that climate change affects the phenological response to a greater degree at higher altitudes than at lower ones.

Table 1: Data of the studied provenances
Few studies have examined differences in frost resistance in beech provenances. Rohmeder (1934, cited in Dolnicki and Kraj, 2001) found that autochthonous stands were most resistant to frost. Pukacki (1990) stated that the eastern limit of common beech distribution is determined by air humidity and the appearance of late frost.

Winter leaf retention has also been little researched. Dunberg (1982) tried to explain the phenomenon as a physiological peculiarity in the juvenile stage of development, while Nilsson (1983) and Escudero and Arco (1987) indicated that this phenomenon is an adaptation to different environmental factors. Herzog and Krabel (1996) compared two neighboring stands of pedunculate oaks growing in the same conditions which had different degrees of leaf retention. They concluded that the phenomenon of leaf retention had a genetic rather than environmental basis.

Journé et al. (2021) investigated if and to what extent canopy duration influences fruit production in three major European deciduous trees: Fagus sylvatica, Quercus robur and Quercus petraea. They used a longterm (11 years) monitoring dataset from 50 populations. In addition to the widely reported main effect of previous summer temperature on fruit production in European beech, they detected a nonlinear relationship between current canopy duration and fruit production. For beech, intermediate canopy duration is associated with the highest fruit production.

This research aims to determine the dates of the beginning and duration of individual phases of leafing,

Preglednica 1: Podatki o preučevanih proveniencah

\begin{tabular}{|c|c|c|c|c|c|c|}
\hline No & Label & Provenance & Country & Latitude & Longitude & Altitude \\
\hline 1 & 9661 & Bos. Krupa Bastra Čorkovaća & $(\mathrm{BiH})$ & $44^{\circ} 45^{\prime}$ & $16^{\circ} 14^{\prime}$ & 720 \\
\hline 2 & 9659 & Bugojno Vranica - Bistrica & $(\mathrm{BiH})$ & $43^{\circ} 33^{\prime}$ & $17^{\circ} 49^{\prime}$ & 750 \\
\hline 3 & 9662 & Dinara & $(\mathrm{BiH})$ & $44^{\circ} 06^{\prime}$ & $16^{\circ} 30^{\prime}$ & 950 \\
\hline 4 & 9633 & Grmeč - Jasenica & $(\mathrm{BiH})$ & $44^{\circ} 16^{\prime}$ & $16^{\circ} 18^{\prime}$ & 450 \\
\hline 5 & 9631 & Konjuh - Kladanj & $(\mathrm{BiH})$ & $44^{\circ} 16^{\prime}$ & $18^{\circ} 34^{\prime}$ & 840 \\
\hline 6 & 9630 & Tajan - Zavidovići & $(\mathrm{BiH})$ & $44^{\circ} 23^{\prime}$ & $18^{\circ} 03^{\prime}$ & 700 \\
\hline 7 & 9632 & Tešanj - Crni Vrh I & $(\mathrm{BiH})$ & $44^{\circ} 33^{\prime}$ & $17^{\circ} 59^{\prime}$ & 500 \\
\hline 8 & 9660 & Tešanj - Crni Vrh II & $(\mathrm{BiH})$ & $44^{\circ} 33^{\prime}$ & $17^{\circ} 59^{\prime}$ & 500 \\
\hline 9 & 9624 & Dilj Čanglinski & $(\mathrm{HR})$ & $45^{\circ} 17^{\prime}$ & $18^{\circ} 01^{\prime}$ & 350 \\
\hline 10 & 9625 & Vran kamen & (HR) & $45^{\circ} 37^{\prime}$ & $17^{\circ} 19^{\prime}$ & 600 \\
\hline 11 & 9646 & Bad Wildbad & (D) & $48^{\circ} 46^{\prime}$ & $08^{\circ} 35^{\prime}$ & 700 \\
\hline 12 & 9642 & Valkonya & $(\mathrm{H})$ & $46^{\circ} 30^{\prime}$ & $16^{\circ} 45^{\prime}$ & 300 \\
\hline 13 & 9649 & Hasbruch & $\mathrm{D}$ & $53^{\circ} 08^{\prime}$ & $08^{\circ} 26^{\prime}$ & 35 \\
\hline 14 & 9648 & Hoellerbach & $\mathrm{D}$ & $49^{\circ} 01^{\prime}$ & $13^{\circ} 14^{\prime}$ & 755 \\
\hline 15 & 9647 & Schwäbisch Alb & $\mathrm{D}$ & $48^{\circ} 00^{\prime}$ & $10^{\circ} 00^{\prime}$ & 650 \\
\hline 16 & 9663 & Alesd & (RO) & $46^{\circ} 10^{\prime}$ & $22^{\circ} 15^{\prime}$ & 490 \\
\hline 17 & 9664 & Alba-Iulia & (RO) & $46^{\circ} 10^{\prime}$ & $23^{\circ} 05^{\prime}$ & 860 \\
\hline 18 & 9666 & Avala & (SRB) & $44^{\circ} 12^{\prime}$ & $20^{\circ} 45^{\prime}$ & 745 \\
\hline 19 & 9669 & Cer & (SRB) & $44^{\circ} 12^{\prime}$ & $19^{\circ} 50^{\prime}$ & 745 \\
\hline 20 & 9668 & Fruška gora & (SRB) & $45^{\circ} 10^{\prime}$ & $19^{\circ} 47^{\prime}$ & 360 \\
\hline 21 & 9643 & Herzogenbuchsee & $(\mathrm{CH})$ & $07^{\circ} 40^{\prime}$ & $47^{\circ} 11^{\prime}$ & 500 \\
\hline 22 & 9665 & Sihlwald & $(\mathrm{CH})$ & $47^{\circ} 12^{\prime}$ & $07^{\circ} 21^{\prime}$ & 1050 \\
\hline
\end{tabular}


the percentage of leaf retention and the degree of plant damage caused by late spring frosts on common beech provenances in the international provenance test in order to identify the best provenance in terms of resistance to late spring and early autumn frosts.

\section{MATERIALS AND METHODS}

\section{MATERIALI IN METODE}

In this research, material from the international provenance test near Kakanj, Bosnia and Herzegovina, was used. The test includes 22 different provenances of common beech: eight from Bosnia and Herzegovina, four from Germany, three from Serbia, two from Croatia, two from Romania, two from Switzerland and one from Hungary (Table 1).

The test was established in spring 2007, in a randomized block system with three replications, with seedlings aged $2+0$ and $3+0$ with a planting spacing of $2 \times 1 \mathrm{~m}$. The test is located at 510 to $540 \mathrm{~m}$ above sea level, at $44^{\circ} 04^{\prime} 15^{\prime \prime} \mathrm{N}, 18^{\circ} 11^{\prime} 32^{\prime \prime} \mathrm{E}$. The average slope of the terrain is about $7 \%$, and the exposure is mostly northeastern. The predominant soil is a rendzina and acid brown soil complex. The surface is influenced by a temperate continental climate characterized by cold winters and moderately warm summers with large amounts of precipitation.

Observations of spring phenology were performed from 31 March 2019 to 18 May 2019. Six phases were observed (according to Forstreuter, 2002):

- A - sleeping bud (winter bud, brown to dark brown in color)

- B - bud swell (elongated, swollen, yellowish-green in color, with a membrane that the tops of the needles have still not pierced)

- C - buds begin to open (cracked) and the first green is visible

- D - curled (rolled) hairy leaves begin to emerge

- E - leaves are unwound, more fan-shaped, pale lamina present

- F - leaves are fully developed, smooth and wide (Fig. 1).

Canopy damage due to the harmful effects of frost that occurred on 8 May 2019 was assessed in three categories: 1 - partial, 2 - moderate and 3 - total canopy damage (Fig. 2).

Winter retention of leaves was evaluated in the spring of 2019 in three categories: 1 - total retention
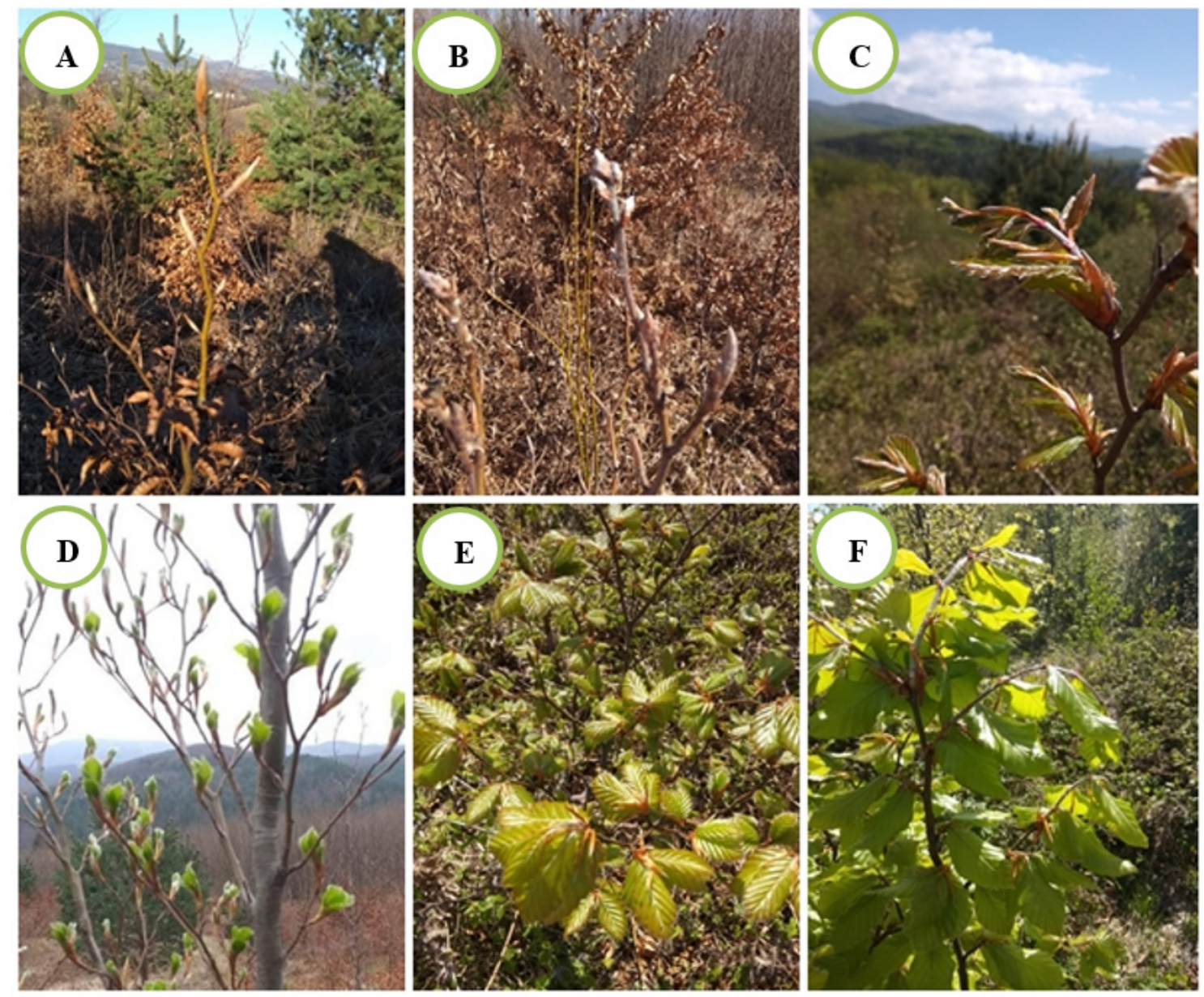

Fig. 1: Observed phenophases of leafing

Slika 1: Opazovane fenofaze razvoja listov 

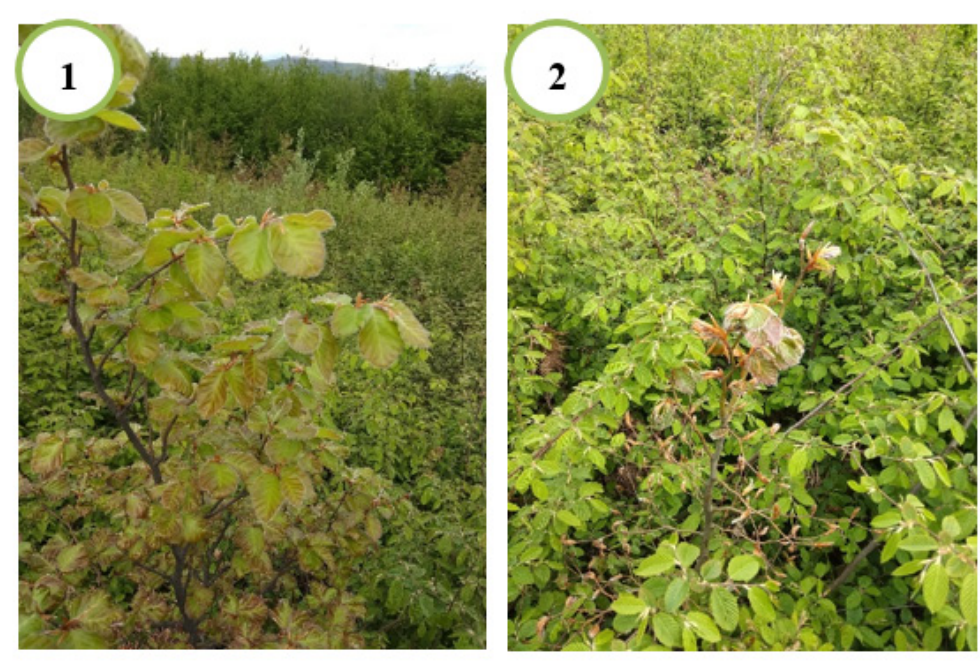

Slika 2: Kategorije škode, ki jo je povzročila pozno pomladanska pozeba
Fig. 2: Categories of damage caused by late spring frost

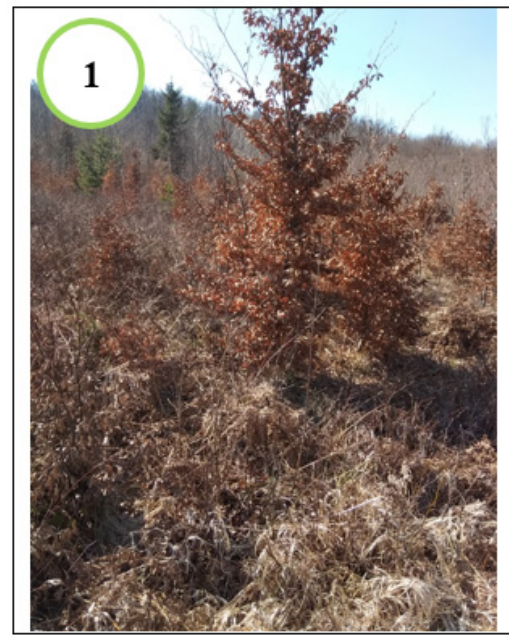

Fig. 3: Categories of winter leaf retention

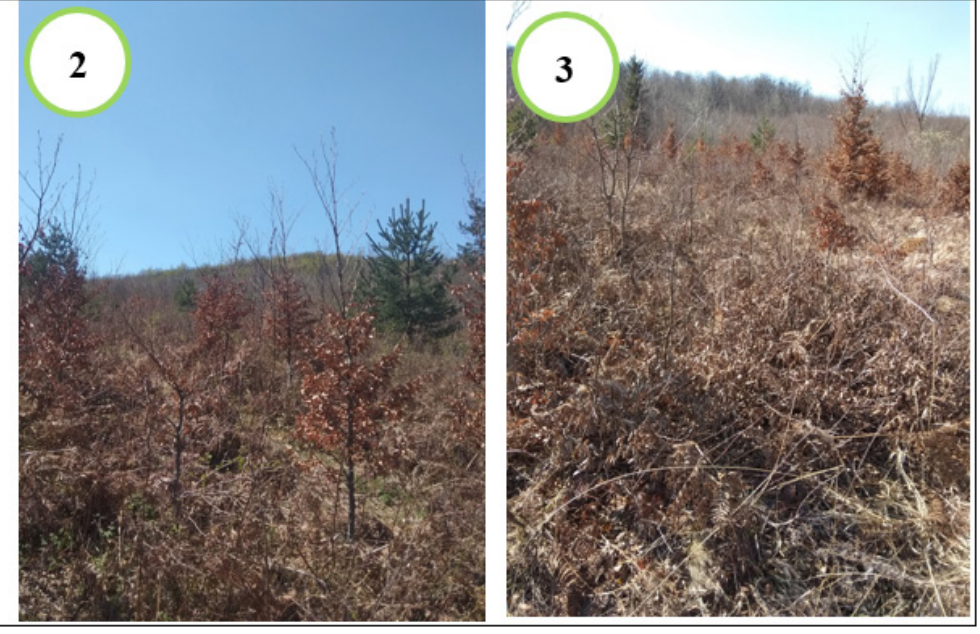

Slika 3: Kategorije zimske retencije listja

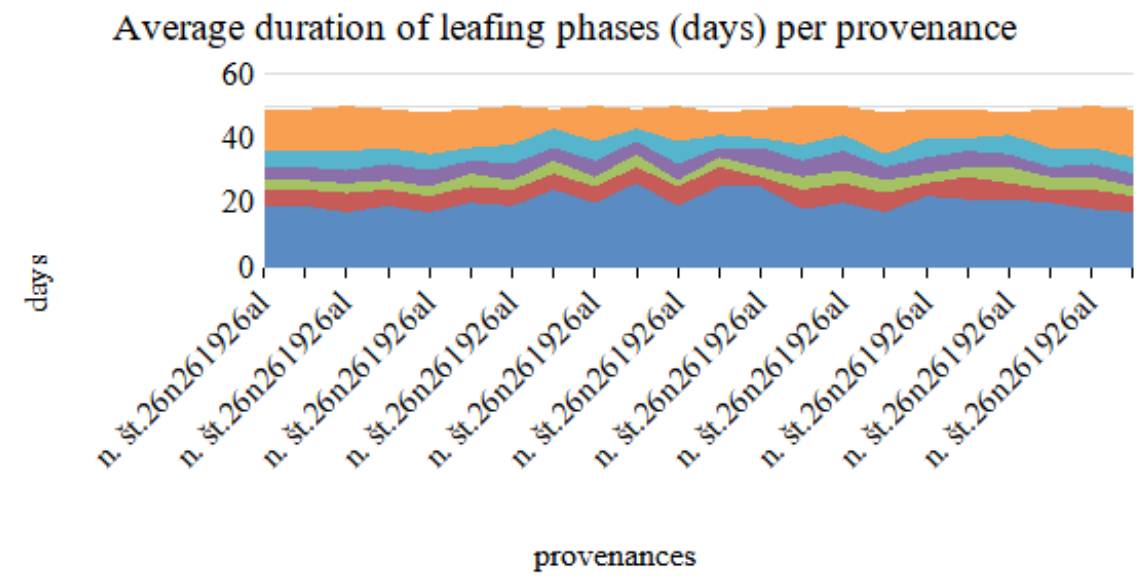

$\square \mathrm{A} \square \mathrm{B} \backsim \mathrm{C} \square \mathrm{D} \square \mathrm{E} \backsim \mathrm{F}$ Mean

Fig. 4: Average duration of leafing phases per provenance
Slika 4: Povprečno trajanje faz razvoja listov po provenienci 
Table 2: The earliest and the latest occurrences of leafing phases per provenance
Preglednica 2: Najbolj zgoden in najbolj pozen pojav faz razvoja listov po provenienci

\begin{tabular}{|c|c|c|c|c|c|c|c|c|c|}
\hline \multirow{3}{*}{ Provenances } & \multicolumn{9}{|c|}{ Phases } \\
\hline & \multicolumn{2}{|c|}{ B } & \multicolumn{2}{|c|}{$C$} & \multicolumn{2}{|c|}{ D } & \multicolumn{2}{|c|}{$E$} & \multirow{2}{*}{$\begin{array}{c}F \\
\text { end }\end{array}$} \\
\hline & beginning & end & beginning & end & beginning & end & beginning & end & \\
\hline 9624 & 14.4. & 2.5. & 14.4. & 2.5. & 20.4 & 2.5. & 26.4. & 11.5. & 26.4 . \\
\hline 9625 & 20.4 & 26.4. & 14.4. & 2.5 & 20.4 & 2.5. & 26.4. & 11.5. & 2.5 \\
\hline 9630 & 7.4. & 26.4. & 14.4. & 2.5. & 20.4. & 2.5. & 26.4. & 11.5. & 2.5. \\
\hline 9631 & 14.4. & 26.4. & 14.4. & 2.5. & 20.4. & 2.5. & 26.4. & 11.5. & 26.4 . \\
\hline 9632 & 14.4. & 26.4. & 14.4. & 2.5 & 20.4. & 2.5 & 26.4. & 11.5. & 26.4 . \\
\hline 9633 & 14.4. & 2.5. & 14.4. & 11.5. & 20.4. & 11.5. & 26.4. & 11.5. & 2.5. \\
\hline 9642 & 14.4. & 26.4. & 20.4 . & 26.4. & 20.4 . & 2.5. & 26.4. & 18.5. & 2.5. \\
\hline 9643 & 20.4 . & 26.4. & 20.4 . & 2.5. & 26.4. & 11.5. & 2.5 & 18.5. & 11.5. \\
\hline 9646 & 14.4. & 2.5. & 20.4. & 2.5. & 26.4. & 2.5. & 26.4. & 11.5. & 2.5. \\
\hline 9647 & 20.4 & 2.5. & 26.4. & 11.5. & 26.4. & 11.5. & 2.5 & 11.5. & 11.5. \\
\hline 9648 & 14.4. & 2.5. & 20.4 . & 2.5. & 26.4. & 11.5. & 26.4. & 11.5. & 2.5. \\
\hline 9649 & 14.4. & 11.5. & 26.4. & 11.5. & 26.4 . & 11.5. & 2.5. & 11.5. & 11.5. \\
\hline 9659 & 20.4 & 2.5 & 26.4 & 2.5 & 26.4 & 11.5. & 2.5 & 18.5. & 2.5 \\
\hline 9660 & 14.4. & 26.4. & 20.4 . & 2.5 & 26.4. & 2.5. & 26.4 . & 11.5. & 2.5. \\
\hline 9661 & 14.4. & 26.4. & 26.4. & 2.5 & 26.4 . & 11.5. & 2.5 & 11.5. & 11.5. \\
\hline 9662 & 14.4. & 26.4 . & 14.4. & 2.5. & 20.4 . & 2.5 & 26.4 . & 11.5. & 2.5 \\
\hline 9663 & 20.4 . & 2.5. & 26.4 . & 2.5. & 26.4 . & 11.5. & 2.5 & 11.5. & 2.5. \\
\hline 9664 & 14.4. & 2.5. & 26.4. & 2.5. & 26.4. & 11.5. & 2.5. & 11.5. & 11.5. \\
\hline 9665 & 20.4 & 2.5. & 26.4. & 2.5. & 26.4 . & 11.5. & 2.5. & 11.5. & 2.5. \\
\hline 9666 & 14.4. & 2.5 & 20.4. & 2.5 & 26.4 . & 11.5. & 26.4 . & 11.5. & 2.5. \\
\hline 9668 & 14.4. & 26.4. & 20.4. & 2.5 & 26.4. & 2.5 & 26.4. & 11.5. & 2.5 \\
\hline 9669 & 14.4. & 26.4 . & 14.4. & 26.4 . & 20.4 . & 2.5. & 20.4 & 11.5. & 26.4 . \\
\hline
\end{tabular}

of leaves, 2 - moderate retention of leaves and 3 - total rejection of leaves (Fig. 3).

\subsection{Statistical data processing}

\subsection{Statistična obdelava podatkov}

Data on the beginnings and ends of the phenological phases of leafing were read using the Excel program, and descriptive data and analysis of variance for the duration of phases were calculated using SPSS 26.0. Data on late frost damage and leaf retention were processed in the SPSS 26.0 program.

Table 3: Analysis of variance of the duration of leafing phases

\section{RESULTS}

\section{REZULTATI}

\subsection{Phenological phases of leafing}

\subsection{Fenološke faze razvoja listov}

Table 2 shows the earliest and latest occurrences of leafing phases per provenance.

The first occurrence of Phase B was recorded on 7 April in the Tajan Zavidovići provenance from Bosnia and Herzegovina.

Figure 4 shows the average duration of leafing phases per provenance.

Preglednica 3: Analiza variance trajanje faz razvoja listov

\begin{tabular}{|c|c|c|c|c|c|c|}
\hline Phase & Source of variability & Sum of Squares & df & Mean Square & $F$ & Sig. \\
\hline \multirow{3}{*}{ A } & Between Groups & 9577.997 & 21 & 456.095 & 15.715 & 0.000 \\
\hline & Within Groups & 28935.962 & 997 & 29.023 & & \\
\hline & Total & 38513.959 & 1018 & & & \\
\hline \multirow{3}{*}{$B$} & Between Groups & 507.194 & 21 & 24.152 & 1.364 & 0.127 \\
\hline & Within Groups & 17658.115 & 997 & 17.711 & & \\
\hline & Total & 18165.309 & 1018 & & & \\
\hline \multirow{3}{*}{ C } & Between Groups & 251.250 & 21 & 11.964 & 1.183 & 0.257 \\
\hline & Within Groups & 10083.305 & 997 & 10.114 & & \\
\hline & Total & 10334.555 & 1018 & & & \\
\hline \multirow{3}{*}{ D } & Between Groups & 454.026 & 21 & 21.620 & 1.911 & 0.008 \\
\hline & Within Groups & 11279.043 & 997 & 11.313 & & \\
\hline & Total & 11733.070 & 1018 & & & \\
\hline \multirow{3}{*}{$E$} & Between Groups & 659.059 & 21 & 31.384 & 2.016 & 0.004 \\
\hline & Within Groups & 15520.765 & 997 & 15.567 & & \\
\hline & Total & 16179.823 & 1018 & & & \\
\hline \multirow{3}{*}{$\mathrm{F}$} & Between Groups & 7444.257 & 21 & 354.488 & 17.141 & 0.000 \\
\hline & Within Groups & 20618.175 & 997 & 20.680 & & \\
\hline & Total & 28062.432 & 1018 & & & \\
\hline
\end{tabular}


Table 3 shows the analysis of variance of the duration of leafing phases.

The analysis of variance showed statistically significant differences for Phases A, D, E and F ( $p<0.05)$.

Duncan's test did not show a separation of provenances by the duration of phenological phases.

\subsection{Canopy damage caused by late spring frost}

3.2 Poškodovanost krošnje po pozno pomladanski pozebi

The percent of plants per category of frost damage for all provenances is shown in Figure 5.

The percent of plants damaged by frost per category and provenance is shown in Figure 6.

Table 4: Analysis of variance for the damage caused by late spring frost
Complete canopy damage affected the highest percentage of plants of provenance 9646 (BW Bad Wildbad, Germany) with $68 \%$, followed by provenance 9665 (Sihlwald, Switzerland) with $64.3 \%$, provenance 9664 (Alba-Iulia, Romania) with $60 \%$ and provenance 9663 (Alesd, Romania) with 57 \%. Provenances 9631 (Konjuh Kladanj, BiH) and 9647 (BW Schwäbisch Alb, Germany) had the lowest percentage of plants with complete canopy damage, with $3.2 \%$ and $12.3 \%$, respectively. The results of the analysis of variance for the damage caused by late frost are shown in Table 4 . It shows the presence of statistically significant differences between provenances.

Preglednica 4: Analiza variance škode po pozno pomladanski pozebi

\begin{tabular}{|l|c|c|c|c|c|}
\hline \multicolumn{1}{|c|}{ Source of variability } & Sum of Squares & df & Mean Square & F & Sig. \\
\hline Between Groups & 83.830 & 21 & 3.992 & 8.130 & 0.000 \\
\hline Within Groups & 489.510 & 997 & 0.491 & & \\
\hline Total & 573.341 & 1018 & & & \\
\hline
\end{tabular}

Percent of plants damaged by frost per category for all provenances

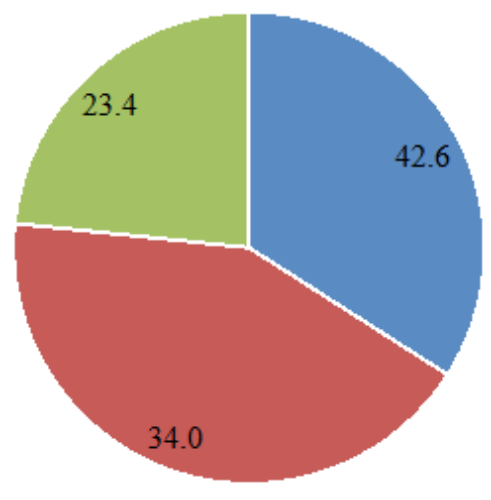

- Total damage

- Moderate damage

n Small damage
Fig. 5: Percent of plants damaged by frost per category for all provenances
Slika 5: Odstotek dreves, poškodovanih v pozebi, po kategorijah za vse provenience

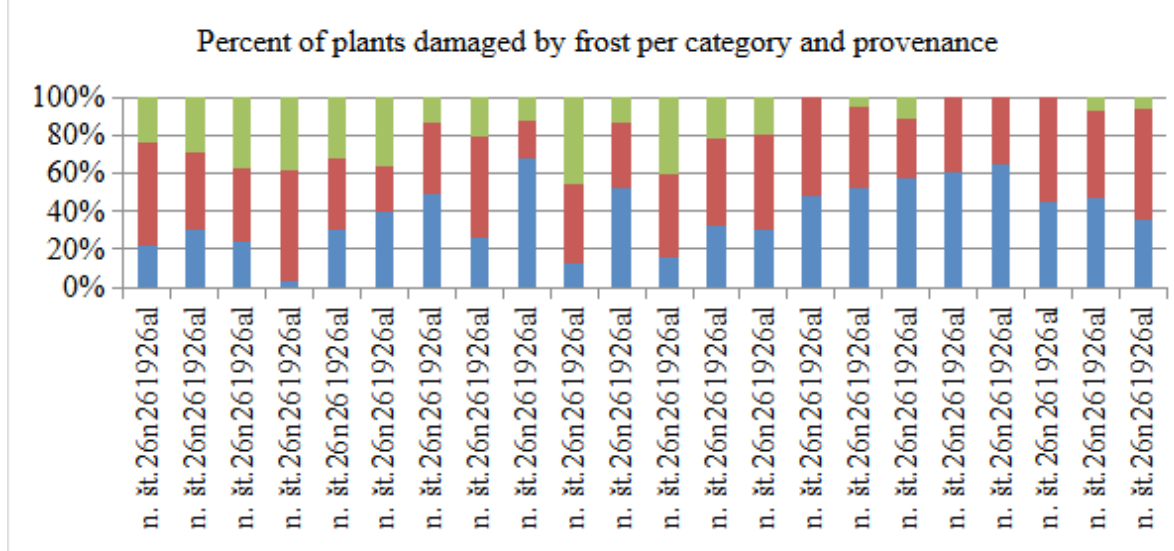

च total damage $\square$ moderate damage $\square$ small damage

Fig. 6: Percent of plants damaged by frost per category and provenance
Slika 6: Odstotek dreves, poškodovanih v pozebi, po kategoriji in provenienci 


\subsection{Winter leaf retention}

\subsection{Zimska retencija listja}

Figure 7 shows the percentage of plants per individual category of winter leaf retention for all provenances together.

The highest percentage of plants had a leaf retention of $50 \%$ ( $43.2 \%$ of the total number of plants), followed by plants with no leaf retention $(38.1 \%$ of the total number of plants) and plants with $100 \%$ leaf retention (18.7 \% of the total number of plants). A graphical representation of winter leaf retention per category and provenance is shown in Figure 8.

Table 5: Analysis of variance for winter leaf retention among provenances
Provenance 9643 (Herzogenbuchsee, Switzerland) had the highest percentage of winter leaf retention with $37.5 \%$ of plants, followed by provenance 9647 (BW Schwäbisch Alb, Germany) with $37 \%$ and provenance 9642 (Valkonya, Hungary) with $30.1 \%$. Provenance 9662 (Dinara, Bosnia and Herzegovina) had the highest percentage of winter non-retention of leaves with $69 \%$, followed by provenance 9669 (Cer, Serbia) with $64.7 \%$. The results of the analysis of variance for the winter leaf retention trait per provenance are shown in Table 5. The results showed statistically significant differences between provenances.

Preglednica 5: Analiza variance zimske retencije listja med proveniencami

\begin{tabular}{|l|c|c|c|c|c|}
\hline \multicolumn{1}{|c|}{ Source of variability } & Sum of Squares & df & Mean Square & F & Sig. \\
\hline Between Groups & 67.481 & 21 & 3.213 & 6.767 & 0.000 \\
\hline Within Groups & 473.433 & 997 & 0.475 & & \\
\hline Total & 540.915 & 1018 & & & \\
\hline
\end{tabular}

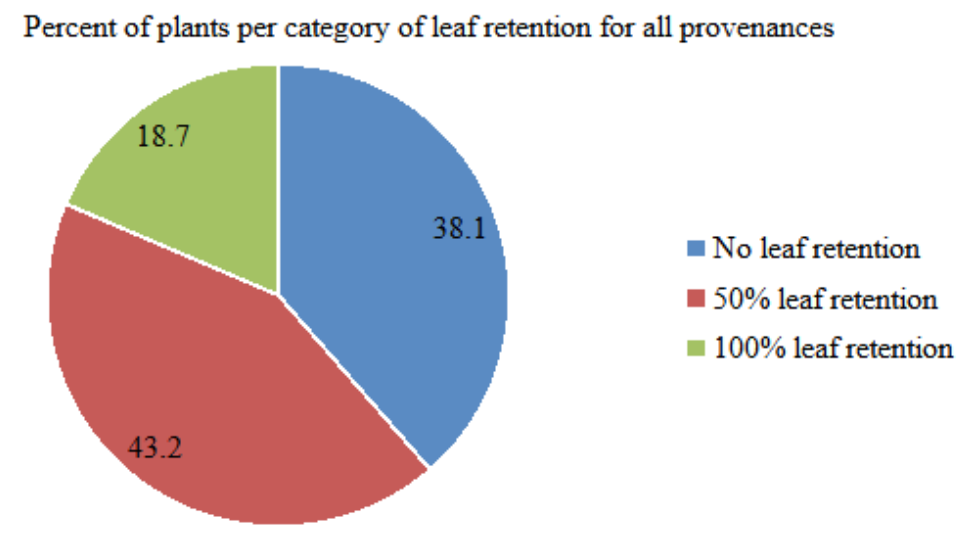

Fig. 7: Percent of plants per category of leaf retention for all

Slika 7: Odstotek dreves po kategoriji retencije listja za vse provenances

provenience

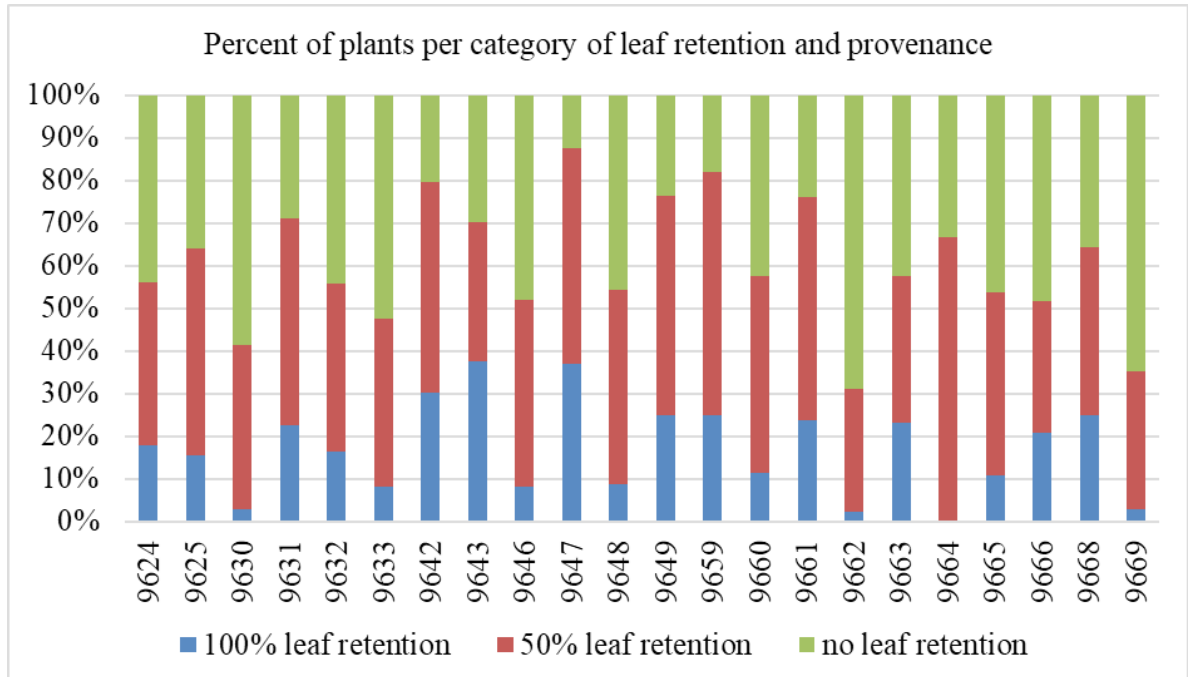

Fig. 8: Percent of plants per category of leaf retention and Slika 8: Odstotek dreves po kategoriji retencije listja in provenance provenienci 


\section{DISCUSSION}

\section{RAZPRAVA}

Multiple years of observation of the phenological phases of beech leafing would most likely determine that the beginning of vegetation depends on spring temperatures as well as on the amount of precipitation. In concave terrain forms, primarily due to low nighttime temperatures, the speed of plant development slows down or accelerates (Kremer, 2001).

After phenological research of different provenances of common beech in the experiment near Kakanj, differences in the timing of the beginning, duration and end of leafing were determined. In the provenance test in 2019, 14 April was found as the beginning of vegetation, which is similar to the results of previous research in this test, and earlier compared to research in Croatia, where Gračan et al. (2006) determined the start of vegetation of common beech to be on 27 April. Tikvić et al. (2006) investigated 58 locations of common beech in Croatia and found 2 May as the average date of leafing development. The authors did not find differences in the beginning of leaf flushing caused by geographic factors. In Slovenia, Čufar et al. (2008) researched different traits in mature beech (Fagus sylvatica L.) trees in a typical forest site near Ljubljana and found leaf unfolding occurred on 16 April. Škrk et al. (2020) recorded general leaf unfolding on different trees of common beech in a site in Ljubljana, Slovenia, between 7 and 25 April. The occurrence and duration of different leafing phases showed great variation within and between trees.

Compared to the research conducted in 2014 (Ballian et al., 2015) and in 2017 (Memišević Hodžić and Ballian, 2021), in this experiment the slight delay of vegetation and the longer period before the start of leafing of certain provenances is likely due to the lower number of days with high temperatures and the long rainy period in May 2019.

Petkova et al. (2017) investigated the spring and autumn phenology of Bulgarian and German provenances of common beech under similar climatic conditions in 2013 and 2016. The results showed that longitude had the greatest impact on the leafing phases.

One of the most important climatic factors impacting forest health is the harmful effects of frost. In valleys, coves and forest clearings, cold air often occurs in the spring, when the temperature drops below $0{ }^{\circ} \mathrm{C}$ in the morning, resulting in extensive damage to young trees. The locality of this provenance test is characterized by frequent temperature inversions. Namely, the test is located in a valley. The surrounding hills prevent the escape of colder and heavier air, which settles in the valley and results in significantly lower temperatures than that in surrounding areas during the winter. Differences in frost resistance in beech provenances have received little research attention. Rohmeder (1934) found that indigenous beech provenances are most resistant to frost and that afforestation with other provenances is not advisable. The results of this experiment showed statistically significant differences in frost resistance between the investigated provenances. Provenances from Germany (BW Schwäbisch Alb and NS Hasbruch) proved to be the most resistant to frost. Also, provenances from Bosnia and Herzegovina showed a high degree of frost resistance. We suggest the use of provenances in which the buds begin to open later as a solution for increasing the resistance of common beech to frost. Such provenances should be applied in places endangered by frost, i.e. in the border areas of the common beech distribution range.

Winter leaf retention is also a physiological trait that has received little research attention. Dunberg (1982) tried to explain the phenomenon as a physiological characteristic in the juvenile stage of development, while other authors indicated that this phenomenon is an adaptation to various environmental factors, such as barren soil, frost, dry or salt-saturated winds, or interspecific competition (Nilsson, 1983; Escudero and Arco, 1987). In this research, we found that provenances from the northern part of the distribution range retained leaves somewhat longer than those from the southern part of the range. However, additional research is needed to draw any firm conclusions with respect to this trait.

Herzog and Krabel (1996) investigated two neighboring pedunculate oak stands growing in the same climatic, edaphic and light conditions. One stand was established in the $1900 \mathrm{~s}$ by planting $1.5 \mathrm{~m}$ high trees 5 $m$ apart, and the other by sowing acorns using 150,000 acorns per ha. Seed sources were unknown and may have differed for the two stands. Leaf retention was observed in the autumn of 1991 and 1992. In both years, almost all trees in the first stand (more than $90 \%$ ) showed normal rejection of older leaves, while more than $80 \%$ of trees in the second stand kept their leaves until the end of the next vegetation period. Isoenzyme analysis of the samples showed that the stand that retained leaves had a higher proportion of rare alleles. The authors considered these results as evidence for the hypothesis that the leaf retention phenomenon has a genetic rather than an environmental basis.

Journé et al. (2021) investigated if and to what extent the canopy duration influences fruit production in three major European deciduous trees: Fagus sylvatica, 
Quercus robur and Quercus petraea. They used a longterm (11 years) monitoring dataset from 50 populations. In addition to the widely reported main effect of previous summer temperature on fruit production in European beech, they detected a nonlinear relationship between current canopy duration and fruit production. For beech, intermediate canopy duration is associated with the highest fruit production.

\section{CONCLUSIONS}

\section{ZAKLJUČKI}

Observations of spring phenology (leafing phases) indicated the existence of differences between provenances in the beginning, duration and end of phenological phases of common beech leafing. As a rule, domestic provenances started leafing phases earlier than foreign ones.

In 2019, for most provenances, the beginning of bud opening was recorded on 14 April.

Provenances from the northern part of the distribution range of common beech retain leaves longer than those from the southern part of the range, but further research is needed to draw any firm conclusions.

In terms of frost resistance, provenances from Germany (BW Schwäbisch Alb and NS Hasbruch, which are also the northernmost provenances in this study) suffered the least canopy damage. In addition, provenances from Bosnia and Herzegovina showed a high degree of resistance to frost.

The Herzogenbuchsee provenance from Switzerland had the highest percentage of winter leaf retention with $37.5 \%$ of plants, followed by the BW Schwäbisch Alb provenance from Germany with $37 \%$ and the Valkonya provenance from Hungary with $30.1 \%$.

Given the above, when choosing seed stands, it is necessary to take into account the physiological characteristics and choose those stands that are genetically significantly resistant to the effects of low temperatures.

\section{SUMMARY}

Common beech is the most represented species in the total area of forests and forest lands in Bosnia and Herzegovina and is therefore of exceptional economic and ecological importance. Research on the spring and autumn phenology of this species is important to predict and prevent damage from late spring and early autumn frosts. The research aimed to determine the start, end and duration of leafing phases, differences in the degree of plant damage caused by late spring frost, and retention of leaves in autumn in the international provenance test of common beech in Bosnia and Herzegovina.
The research was conducted in the international common beech provenance test in Bosnia and Herzegovina near Kakanj. The test contains eight provenances from Bosnia and Herzegovina, four from Germany, three from Serbia, two each from Croatia, Romania and Switzerland, and one from Hungary. Leafing phenology, canopy damage caused by late spring frost, and leaf retention were assessed in 2019. Observations of spring phenology were performed from 31 March 2019 to 18 May 2019. Six phases were observed (according to Forstreuter, 2002): A - sleeping bud (winter bud, brown to dark brown in color); B - bud swell (elongated, swollen, yellowish-green in color, with a membrane that the tops of the needles have still not pierced); C - buds begin to open (cracked) and the first green is visible; $\mathrm{D}$ - curled (rolled) hairy leaves begin to emerge; E - leaves are unwound, more fan-shaped, pale lamina present; $F$ - leaves are fully developed, smooth and wide. Canopy damage due to the harmful effects of frost that occurred on 8 May 2019 was assessed in three categories: 1) partial , 2) moderate and 3) total canopy damage. Winter retention of leaves was evaluated in the spring of 2019 in three categories: total retention of leaves, moderate retention of leaves and total rejection of leaves. Data were recorded and processed using IBM SPSS 26.0. The duration of phenophases per provenance, analysis of variance for the duration of phenophases per provenance, percentage of frost damage per category per provenance, and the percentage of leaf retention per category per provenance were calculated.

The analysis of variance showed statistically significant differences in the duration of leafing phenophases between provenances. As a rule, domestic provenances started leafing phases earlier than foreign ones. Most provenances started opening buds on 17 April.

In terms of frost resistance, provenances from Germany (BW Schwäbisch Alb and NS Hasbruch, which are also the northernmost provenances in this study) suffered the least canopy damage. In addition, a high degree of resilience was shown by provenances from Bosnia and Herzegovina.

The Herzogenbuchsee provenance from Switzerland had highest percentage of winter leaf retention with $37.5 \%$ of plants, followed by the BW Schwäbisch Alb provenance from Germany with $37 \%$ and the Valkonya provenance from Hungary with $30.1 \%$. Northern provenances seem to retain leaves longer than those from the southern part of the range of common beech, but additional research is necessary to draw firm conclusions with respect to this trait.

Given the above, when choosing seed stands, it is necessary to take into account the physiological char- 
acteristics and choose those stands that are genetically significantly resistant to the effects of low temperatures.

\section{POVZETEK}

Navadna bukev je najbolj pogosta drevesna vrsta na območju gozdov in gozdnih zemljišč v Bosni in Hercegovini in je zato ekonomsko in ekološko izjemno pomembna. Raziskave o pomladanski in jesenski fenologiji te vrste so pomembne za napovedovanje in preprečevanje škode po pozno pomladanski in zgodnje jesenski pozebi. Namen raziskave je bil določiti začetek, konec in trajanje fenoloških faz, stopnjo škode, ki jo povzroči pozno pomladanska pozeba, in jesensko retencijo listja na območju mednarodnega provenienčnega poskusa navadne bukve $\mathrm{v}$ Bosni in Hercegovini blizu Kakanja.

Poskus obsega osem provenienc iz Bosne in Hercegovine, štiri iz Nemčije, tri iz Srbije, po dve iz Hrvaške, Romunije in Švice ter eno iz Madžarske. Leta 2019 so bile ocenjene fenologija listja, škoda na krošnjah zaradi pozno pomladanske zmrzali in retencija listja. Opazovanja pomladanske fenologije so bila opravljena od 21. marca do 18. maja 2019. Opazovali smo šest faz (po Forstreuterju, 2002): A - speči brst (zimski brst, rjave do temno rjave barve); $\mathrm{B}$ - nabreknjen brst (podaljšan, nabreknjen, rumeno-zelene barve, z membrano, ki je vrhovi listov še niso prebodli); C - brsti se pričnejo odpirati (počijo) in vidna je prva zelena; D - začnejo se pojavljati kodrasti (zaviti) kosmati listi; E - listi so odviti, bolj pahljačasti, prisotna bleda listna ploskev; F listi so polno razviti, gladki in široki. Poškodbe krošenj zaradi škodljivih vplivov pozebe 8. maja 2019 so bile ocenjene $v$ treh kategorijah; 1) delno, 2) zmerno in 3) $\mathrm{v}$ celoti poškodovana krošnja. Zimska retencija listja je bila ocenjena pomladi $2019 \mathrm{v}$ treh kategorijah: popolna retencija listja, zmerna retencije listja in popolno odvrženje listja. Podatki so bili zbrani in zabeleženi s programom IBM SPSS 26.0. Izračunali smo trajanje fenofaz na proveniencah, analizo variance za trajanje fenofaz na proveniencah, odstotek škode po pozebi na kategorijo in na provenienco, in delež retencije listja na kategoriji in na provenience.

Analiza variance je pokazala statistično značilne razlike med trajanjem listnih fenofaz glede na provenience. Praviloma so domače provenience začele razvijati listne faze prej kot tuje provenience. Pri večini provenience so se brsti začeli odpirati 17. aprila.

Kar se tiče odpornosti na pozebo so provenience iz Nemčije (BW Schwäbisch Alb in NS Hasbruch, ki so tudi najbolj severne provenience $\mathrm{v}$ tej raziskavi) utrpele najmanjšo škodo na krošnjah. Tudi prove- nience iz Bosne in Hercegovine so izkazale visoko raven odpornosti.

Provenienca Herzogenbuchsee iz Švice je imela najvišji delež zimske retencije listja (37,5 \% dreves), sledila ji je provenienca BW Schwäbisch Alb iz Nemčije s $37 \%$ in provenienca Valkonya iz Madžarske s 30,1 $\%$. Severne provenience očitno listje zadržijo dlje kot tiste na južnem območju razširjenosti navadne bukve, vendar pa so za bolj dokončne zaključke glede te karakteristike potrebne dodatne raziskave.

Glede na rezultate je treba pri izbiri semenskih sestojev upoštevati fiziološke lastnosti in izbrati sestoje, ki so genetsko značilno odporni na učinke nizkih temperature.

\section{REFERENCES}

\section{VIRI}

Ballian D. 2010. An overview of European beech (Fagus sylvatica L.) in Bosnia and Herzegovina. Communicationes Instituti Forestalis Bohemicae, 25: 52-60.

Ballian D., Jukić B. Balić B., Kajba D., Von Wüehlisch G. 2015. Fenološka varijabilnost obične bukve (Fagus sylvatica L.) u međunarodnom pokusu provenijencija. Šumarski list, 139, 11-12: 521-533.

Ballian D., Westergern M., Kraigher H. 2019. Varijabilnost obične bukve (Fagus sylvatica L.) u Bosni i Hercegovini. Sarajevo, Udruženje inženjera i tehničara šumarstva Federacije Bosne i Hercegovine: 229 str.

Ballian D., Zukić N. 2011. Analiza rasta provenijencija obične bukve (Fagus sylvatica L.) u međunarodnom pokusu kod Kaknja. Radovi Šumarskog fakulteta Univerziteta u Sarajevu, 41, 2: 75-91.

Ballian D., Bogunić F., Mujezinović O., Kajba D. 2012. Genetska diferencijacija obične bukve (Fagus sylvatica L.) u Bosni i Hercegovini. Šumarski list, 136, 11-12: 587-595.

Čufar K., De Luis M., Saz M.A., Črepinšek Z., Kajfež-Bogataj L. 2012. Temporal shifts in leaf phenology of beech (Fagus sylvatica) depend on elevation. Trees, 26: 1091-1100. https://doi. org/10.1007/s00468-012-0686-7

Čufar K., Prislan P., de Luis M., Gričar J. 2008. Tree-ring variation, wood formation and phenology of beech (Fagus sylvatica) from a representative site in Slovenia, SE Central Europe. Trees, 22: 749-758. https://doi.org/10.1007/s00468-008-0235-6

Dolnicki A., Kraj W. 2001. Leaf morphology and the dynamics of frost-hardiness of shoots in two phenological forms of European beech (Fagus sylvatica L.) From Southern Poland, EJPAU, 4 (2), 01.

Dunberg A. 1982. Why beech and oak trees retain leaves until spring: a comment on the contribution by Otto and Nilsson. Oikos, 39: 275-277.

Escudero A., Arco J.M. 1987. Ecological significance of the phenology of leaf abscission. Oikos, 49: 11-14.

Forstreuter M. 2002: Auswirkungen globaler Klimaänderungen auf das Wachstum und den Gaswechsel (CO2 /H20) von Rotbuchenbeständen (Fagus sylvatica L.). Berlin, Germany: TU Berlin.

Fukarek P. 1970. Areal rasprostranjenosti bukve, jele i smrče na području Bosne i Hercegovine. Radovi ANUBIH 39, 11: 231-256.

Geßler A., Keitel C., Kreuzwieser J., Matyssek R., Seiler W., Rennenberg H. 2007. Potential risks for European beech (Fagus sylvatica L.) in a changing climate. Trees, 21:1-11. DOI 10.1007/ s00468-006-0107-x. 
Gordo O., Sanz J.J. 2010. Impact of climate change on plant phenology in Mediterranean ecosystems. Global Change Biology, 16, 3: 1082-1106.

Gračan J., Ivanković M., Marijanović H., Perić S. 2006. Istraživanje uspijevanja provenijencija domaćih i stranih vrsta drveća, s osvrtom na međunarodni pokus provenijencija obične bukve (Fagus sylvatica L.). Radovi Šumarskog instituta Jastrebarsko, Izvanredno izdanje 9: 337-352.

Herzog S., Krabel D. 1996. Genetic studies on leaf retention in Quercus robur. Silvae Genetica, 45: 272-276.

Journé V., Caignard T., Hacket-Pain A., Bogdziewicz, M. 2021. Leaf phenology correlates with fruit production in European beech $(\mathrm{Fa}$ gus sylvatica) and in temperate oaks (Quercus robur and Quercus petraea). European Journal of Forest Research, 140: 733-744. https://doi.org/10.1007/s10342-021-01363-2

Kremer D. 2001. Fenološka zapažanja cvatnje nekih drvenastih vrsta u botaničkom vrtu prirodoslovno-matematičkog fakulteta sveučilišta u Zagrebu. Šumarski list, 125, 9-10: 475-486.

Liesebach M., Degen B., Scholz F. 1999. Zur genetischen Anpassungsfähigkeit der Rotbuche (Fagus sylvatica L.). Berichte über Landwirtschaft, 77: 128-133.

Memišević Hodžić M., Ballian D. 2021. Morfološka i fenološka varijabilnost obične bukve (Fagus sylvatica L.) u međunarodnom testu provenijencija u Bosni i Hercegovini. Šumarski list, 145, 1-2: 19-30. DOI: 10.31298/sl.145.1-2.2,
Muhs H.-J. 1985. International provenance trial of beech (Fagus sylvatica L.) from 1983/85. Mitteilungen der Bundesforschungsanstalt für Forst-und Holztechnologie, 3. IUFRO Buchensymposium: 77-83.

Nilsson S.G. 1983. Evolution of leaf abscission times: alternative hypotheses. Oikos, 40: 318-319.

Petkova K., Molle E., Huber G., Konnert M., Gaviria J. 2017. Spring and autumn phenology of Bulgarian and German provenances of Common beech (Fagus sylvatica L.) under similar climatic conditions. Silvae Genetica, 66: 24-32.

Pukacki P. 1990. Odpornosć na niskie temperatury. In: Buk zwyczajny (Fagus sylvatica L.). Białobok S. (ed.). Warszawa, Państwowe wydawnictwo naukowe: 185-192.

Škrk N., Črepinšek Z., Čufar K. 2020. Phenology of leaf development in European beech (Fagus sylvatica) on a site in Ljubljana, Slovenia in 2020. Les/Wood, 69, 1, 5-19. https://doi.org/10.26614/ les-wood.2020.v69n01a07

Tikvić I., Španjol Ž., Ugarković D., Seletković Z., Barčić D. 2006. Development of leaf phenophases of European beech (Fagus sylvatica L.) in Croatia in relation to ecological factors. Periodicum Biologorum, 108, 6: 677-682.

Von Wühlisch G., Krusche D., Muhs J. 1995. Variation in temperature sum requirement for flushing of beech provenances. Silvae Genetica, 44: 343-346. 
